\title{
Poppay (Products Processed of Papaya) Productivity Improvement And Innovation at Macanputih Village
}

\author{
A.A. Gde Satia Utama ${ }^{1}$, Dian Pratama ${ }^{2}$ \\ \{gde.agung@feb.unair.ac.id ${ }^{1}$, dian.pratama-2017@feb.unair.ac.id² $\}$ \\ ${ }^{1}$ Department of Accounting, Universitas Airlangga, Surabaya, Indonesia
}

\begin{abstract}
Macanputih village, one of the villages in the district Kabat where is $75 \%$ of the population works in the agricultural sector. Papaya is a great potential which is owned but has less value. One papaya fruit is only sold Rp. 3,000 - Rp. 5000. It is not comparable to the costs incurred. Starting from the purchase of seed, treatment, fertilizer, until the cost of harvesting. In addition to a cheap price, papaya also have the potential resistance, PSDKU accounting students of Airlangga University in Banyuwangi, Class of 2018 held a community service event. The theme of this event is the empowerment and training people to produce a variety of processed papaya. This is an innovation to increase the sale value of papaya which has been underestimated, even only as a dessert .Product introduced by accounting students in the form of jam and coffee from papaya seeds, this activity is expected to farmer groups and communities in Macanputih capable of processing the papaya fruit into products that have a higher resale value, so can increase the productivity of its people. In addition, it is expected from these activities of the villagers Macanputih able to branding their village into a tourist village of papaya preparations. Further, it is expected not only processed papaya jam and coffee beans, but also a variety of other innovative products. This event is expected to farmer groups and communities in Macanputih capable of processing the papaya into products that have a higher resale value, so as to improve the productivity of its people
\end{abstract}

Keywords: Poppay, Macanputih, Community, Papaya, Productivity

\section{Introduction}

Macanputih Village, is one of the villages in the district Kabat. $75 \%$ of the population Macanputih, work in the agricultural sector. As the area is still fertile, Macanputih has a wide range of potential crops, one of which is the fruit of papaya. Seeing the potential content of the papaya fruit, accounting student PSDKU Airlangga University in Banyuwangi, Class of 2018 held a community service event, which is a manifestation of one of the Tri Dharma Perguruan Tinggi. Theme in this event is the empowerment and training villagers to produce a variety processed papaya. Products introduced by this accounting students in the form of papaya jam and coffee from papaya seeds. This activity is expected to farmer groups and communities in Macanputih is capable of processing the papaya into a commodity product that has a higher sales value, thus increasing productivity and people's income. In addition, expected from this activity is Macanputih Village Society was able to branding village into a village of processed papaya (kampung poppay). 


\subsection{Comunity Development Purpose}

a. To determine the potential of what is owned by the village Macanputih, which will be developed by us.

b. To determine whether the potential that exists in the village has been used optimally Macanputih which will be the basis of the implementation of community service activities

\subsection{Benefits or Comunity Development}

a. Macanputih make rural communities more productive, by optimizing the potential of papaya

b. Preparing Macanputih into a tourist village education Poppay (Products Processed papaya)

\subsection{Formulations of the Problem}

a. How to invite villagers Macanputih to optimize the potential of the papaya into innovative products

b. How to invite villagers Macanputih to make the village into a tourist village VILLAGE education Poppay (Products Processed papaya).

\section{Literature Review}

\subsection{Narative about Papaya}

Papaya [1][2] is a tropical plant that can be found throughout Indonesia. Papaya fruit gummy and fruit fleshy red or yellow, and contains lots of fiber[3]. During this time, papaya low commercial value, as well as a lot is wasted due to rapid decay. Yet, papaya fruit can be processed into processed more durable, and has a sale value. Meat papaya fruit itself can be utilized as processed papaya jam, as well as the seeds can be processed into coffee papaya seeds.

Papaya one of the fruits that contain fiber, vitamin A, vitamin B komleks, Vitamin C, Bcarotene, pectin, D-galactose, I - arabinose, papain, papayotimin, and vitokinase. Papaya seeds contain a glucoside Kasirin and karpain. Every $25 \%$ of medium size papaya fruit equivalent $76 \mathrm{~g}$ contains 30 calories, $89 \%$ water, $0.5 \mathrm{~g}$ protein, $8 \mathrm{~g}$ karbohitdrat, $2 \mathrm{~g}$ fiber, $1 \mathrm{mg}$ potassium, $18 \mathrm{mg}$ calcium, magnesium $8 \mathrm{mg}, 4 \mathrm{mg}$ of phosphorus, $22 \mathrm{IU}$ of vitamin A, $47 \mathrm{mg}$ vitamin C, $1 \mathrm{mg}$ of vitamin E, $1 \mathrm{mg}$ of niacin, folic micrg 29 [3]. Besides meat that can be used as preparations and also facilitate the digestive system, and contains high vitamins A, papaya seeds also have health benefits. Papaya seeds can be used as medicine for diarrhea, and treat skin diseases [4$6]$.

\subsection{Purpose of KAMPUNG POPPAY}

Kampung Poppay (Products Processed papaya village) is an innovation to help improve productivity Macanputih rural communities, through the optimization potential of papaya fruit. This program aims to turn the village into a tourist village Macanputih education about papaya processing, starting from the planting to processing. The program started with the holding of training to make papaya jam and coffee from papaya seeds. Then proceed with assistance on an ongoing basis for the establishment of Kampung Poppay educational tour 


\subsection{Methods}

Methods of community service that we do is the following:

a. Socialization about the potential that exists in the village Macanputih, along with the purpose of implementation of community service.

b. Socialization of product-related innovations that have been made, benefits, and potential sales value.

c. Training the manufacture of a product, from raw materials, processing, up to the packaging and distribution process.

d. Facilitation of farmer groups and rural communities in realizing Macanputih as Kampung Poppay (Products Processed papaya Village).

\section{Discussion}

From the observation that we do Macanputih village, the village has the potential of papaya fruit in abundance. But the abundant potential has not been used optimally by the community. Papaya fruit produced only sold directly without prior processing [7] . It make papaya sales value is low, and is not comparable to the costs incurred to grow and care. From these results we took the initiative to carry out community service in the form of training, and mentoring existing farmer groups, to be able to cultivate papaya that has a higher resale value. This community service we do to optimize the potential of papaya fruit, while increasing productivity of Macanputih communities [8]

Community service that we do aims to make the village as Kampung Poppay Macanputih (Products Processed papaya village). In addition to increasing the productivity of society through the processing of papaya, expected outcomes of community service activities that we did were able to make Macanputih village as a tourist destination papaya processing education in Banyuwangi. So in addition to increasing rural incomes Macanputih, was also able to increase the number of tourists visiting Banyuwangi. In this activity, we do socialization about the potential that exists in the village Macanputih, as well as the purpose of the community service activities that we do. After socializing, our team also explained the related product innovations that have been made, benefits, and potential resale value. The products we intriduced are papaya jam and coffee from papaya seeds. Both products that we introduce this we named OPPAY (Processed papaya).

After introducing the products we make, our team conducted training on making jam and coffee from papaya seeds. This training we give to the representatives of farmers' groups are present [9] Hopefully, representatives at the community can be a promoter in optimizing the papaya fruit processing into products - other innovative products [10-12]. After carrying out training on making papaya fruit processed products, we intend to carry out assistance to rural communities Macanputih. Assistance will we do is related to the monitoring of the development of rural communities post their Macanputih Kampung Poppay program.

\subsection{Method for making jam papaya}

a. Separate the flesh from the peel papaya

b. Clean first, then puree

c. Cook and mix with other ingredients, until thickened and make jam 


\subsection{The method of making coffee from papaya seeds}
a. Separate the seeds Papaya with meat
b. Clean the papaya seeds
c. Drying the seeds are clean
d. Roasted dried papaya seeds
$e$. Puree papaya seeds that have been roasted

\subsection{Product}

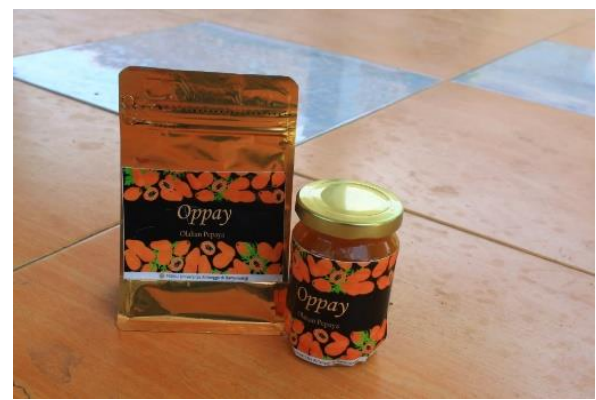

Fig. 1. Product OPPAY (Processed papaya).

\section{Conclusion}

Through this community service program, Macanputih rural communities will be able to optimize all the potential that exists in the region in a more innovative, to build an independent economy. One of the things that can be done is, the implementation of a papaya fruit product processing on an ongoing basis and seek the establishment of a tourist village Poppay education, and continuously carried out the latest innovations. Our hope in the future of rural communities Macanputih Kampung Poppay able to continue this program, in addition we also hope that the future of society are able to make the latest product innovations from the potential that exists in the village, not only of processed fruit papaya, but also other potential possessed.

\section{References}

[1] Aditya Marianti, \& Lina Herlina, \& W. S. (2017). Optimalisasi Pemanfaatan Pekarangan Rumah Sebagai Kebun Sayuran Organik Di Desa Wisata Kandri Dan Pengembangannya Sebagai Destinasi Agrowisata. Majalah Aplikasi Ipteks NGAYAH, 8(1), 85-98.

[2] Bin, A. (2012). Produk diversifikasi olahan untuk meningkatkan nilai tambah dan mendukung pengembangan buah pepaya ( Carica papaya L ) di Indonesia. Buletin Teknologi Pascapanen Pertanian, 8(2), 62-70.

[3] Cahyati, W. H. (2013). Konsumsi Pepaya (Carica Papaya) Dalam Menurunkan Debris Index. Jurnal Kesehatan Masyarakat, 8(2), 127-136. Retrieved from http://journal.unnes.ac.id/nju/index.php/kemas 
[4] Fauzan, R. (2018). Karakteristik Model Dan Analisa Peluang-Tantangan Industri 4.0. Jurnal Teknik Informatika Politeknik Hasnur, 04(April), 1-11.

[5] Panggabean, D. D., Cerah, A., Azis, K., \& Syah, D. H. (2018). Peningkatan Daya Saing Produk Industri Rumah Tangga Bon Bon Santan Sonjay Di Kota Medan. Jurnal Pembangunan Perkotaan, 6(1), 40-45. Retrieved from http://ejpp.balitbang.pemkomedan.go.id/index.php/JPP

[6] Lestari, A. R. A., Syahfitri, S. A., Cahyo, S. T., Wardaniati, I., \& Herli, M. A. (2018). Aktivitas Antibakteri Seduhan Biji Pepaya ( Carica papaya L ) Terhadap Escherichia coli, Salmonella thypi dan Staphlycocus aureus, I, 39-45. Retrieved from http://jim.unsyiah.ac.id/FKH/article/view/8227/3535

[7] Noviana, Z. R., Choiriyah, W., Purnomo, R. A. (2018). Pengembangan ekowisata gunung beruk dan pembuatan cinderamata dari potensi alam sekitar berbasis pemberdayaan masyarakat. Seminar Nasional Dan Call For Paper III, 534-539.

[8] Nurihardiyanti, Yuliet, I. (2015). Aktivitas Diuretik Kombinasi Ekstrak Biji Pepaya (Carica Papaya L) Dan Biji Salak (Salacca Zalacca Varietas Zalacca (Gaert.)Voss) Pada Tikus Jantan Galur Wistar (Rattus norvegicus L). Journal of Pharmacy, 1(October), 105-112.

[9] Rahma, F., Ristiyanti, N., \& Debora, S. T. (2018). Solusi Upgrading terhadap Rantai Nilai Global dalam Industri Kluster Gerabah di Kasongan , Bantul. Jurnal Transborders, 1(2), 94 112.

[10] Sari, Yuliana Windi. (2016). Bumdesa ( Badan Usaha Milik Desa ) Sebagai Kelembagaan Partisipatoris Untuk Pengembangan Identifikasi Potensi Masyarakat Pedesaan. Prosiding SEMATEKSOS 3 "Strategi Pembangunan Nasional Menghadapi Revolusi Industri 4.0," 298-302.

[11] Utami, A. T. (2017). Home Country Features dalam Mendukung Internasionalisasi Perusahaan (Studi Kasus : Internasionalisasi Foxconn). Jurnal INSIGNIA, 4(2), 9-20.

[12] Wisnantiasri, \& S. N. I. P. S. \& F. N. \& K. S. (2018). Pelatihan Pembuatan Laporan Keuangan Bagi UMKM Sebagai Informasi Untuk Pengambilan Keputusan. Jurnal $\begin{array}{llll}\text { Pemberdayaan } \quad \text { Masyarakat } \quad \text { Madani } & \text { (JPMM), } & \text { 63-82. }\end{array}$ https://doi.org/https://10.21009/JPMM.002.1.05 